\title{
Practicing Indigeneity: Lessons from a Māori - School Governance Partnership
}

\author{
Te Kawehau Hoskins (Ngāti Hau, Ngāpuhi) \\ The University of Auckland, Aotearoa New Zealand \\ tk.hoskins@auckland.ac.nz
}

Having grown up connected to Māori politics and struggles for cultural revitalization, rather than being a beneficiary of them, it was inevitable I would be involved in Māori education once I had children myself. Māori educational settings have become a significant site of my political and cultural activism. Involvement in such sites has meant a journey into Māori educational initiatives and has also coincided with an academic career in the field of education.

I am not a trained teacher; rather my involvement in Māori education has always been located in whānau (kin families and/or groups sharing a focus/activity) and community. I therefore approach Māori schooling from a position that centers community in determining educational priorities. Involvement in Māori schooling initiatives means many hours of voluntary work. Because I view grass-roots political and cultural activities as particularly powerful and creative sites for change, I have always been excited by the remarkable opportunity there is in Māori schooling initiatives to create the kinds of educational initiatives envisioned by whānau and community. Having been a parent in Kōhanga Reo (Māori language pre-schools) where whānau are the administrators, managers, employers and day-to-day helpers; I have continued to take a hands-on and whānau-determined approach to the other Māori school settings in which I am involved. My experience has been that where community and whānau view themselves, and therefore act as a collective of educators, activists and learners in relation to schooling, productive and positive outcomes follow.

What I share here is a particular community's unique and visionary practice for the education of their children. It is an account of an inner city 'mainstream' primary school, in Auckland, Aotearoa New Zealand, that is organized around a co-governance relationship based on the Treaty of Waitangi (1840). In this school, two forms of authority (Māori and Crown), and ways of constituting social and educational space are recognized and practiced. Because these governance arrangements position Māori autonomously and relationally, Māori are actively and creatively determining their own educational priorities and practices with significant success. This account can be read as a productive example of the possibilities for ethical and political practice, in a range of sites across our Indigenous worlds.

\section{Treaty Co-Governance at Newton Central School}

The school Board of Trustees and a representative Māori community group, Te Whao Urutaki, together govern Newton Central School. The governance structure is based on an agreed interpretation that the Treaty of Waitangi affirmed ongoing hap $\bar{u}^{\text {ii }}$ Māori authority (rangatiratanga). In the context of the school, this means authority over Māori education and a shared responsibility for governance of the whole school.

These co-governance arrangements at Newton Central School came into being in 2001, and at a time where the school already had flourishing well supported Māori language pathways. A 
serious conflict between the Māori school community and school management then occurred indicating that, despite good relations and support for Māori education, assumptions had been made by the Māori community about the scope of their authority over Māori matters in the school. Questions about Māori authority and participation in school governance pointed to the Treaty as the appropriate paradigm through which to orient discussions with the Board of Trustees.

The Māori language version of the Treaty of Waitangi (1840) cedes "kawanatanga" ('governorship/governance' iii) to the Crown in Article One, while affirming in Article Two the "tino rangatiratanga" (unqualified authority) of hapū (Māori tribal groups) over all things valued by them. The position forwarded by the Māori community, and dominantly held by Māori is that Māori-hapū did not cede sovereignty by the Treaty. The Treaty rather affirmed Māori authority, while consenting to 'kawanatanga' - governance primarily over British settler-subjects. Newton Central's Treaty of Waitangi policy (2001) sought to partner these two forms of authority, which arguably do not fit neatly together, within the state-sanctioned governance structure of a school. In many respects, the governance partnership at Newton Central is an attempt to affect the fullest expression of tino rangatiratanga (hapū-Māori authority) possible, in a political context where kawanatanga (Crown governance) has become the dominant authority.

Establishing two governance partners pointing to two concepts, forms and practices of authority (even as there are a set of legal requirements to be met) interrupts the Western (and commonsense) assumption of a singular and unified form of authority. It acknowledges the 1840 Treaty of Waitangi as establishing a relationship rather than subsuming Māori within the nation state (or in this case, the Board of Trustees) and the ongoing working out of the relationship between them.

The Treaty Governance partnership was cleverly established via Newton Central School's policy-making process. New Zealand schools are self-governing, which means there exists a measure of flexibility in determining policy and governance arrangements in schools as long as there is consensus for them, and they don't break the law. Using the school policy- making process we developed a Treaty of Waitangi policy that in effect restructured the governance of Newton Central School into a partnership between the Board of Trustees and Te Whao Urutaki (representing the Māori school community and Māori-hapū interests). Kawanatanga is recognized in the Board and its legal accountability to the state. Rangatiratanga is recognized in the Māori community (represented by Te Whao Urutaki). Because all aspects of the school affect and are of value to Māori (rather than simply the Māori language pathways), Te Whao Urutaki and the Board together govern all aspects of the school. The Treaty of Waitangi policy is positioned as the 'overarching' school policy and all other policies are referenced to it.

The policy agrees that the Board will not enact its voting powers to outbid or outvote the Māori community where disagreement or conflict arises. Rather, a governance process is established that is committed to consensus decision-making and has operated successfully since its inception. Because the policy specifies decisions are made by the two partners via consensus, the Māori community in effect has a power of veto because both partners must reach agreement. In addition to encouraging meaningful engagement and relational trust, the consensus approach avoids the need for equal numbers of both partners to be present at meetings and formalized as Board members (as would be needed in a majority rules process). In New Zealand law there is only one Board of Trustees for each school. To accommodate a co-governance relationship within this structure, the 
school utilizes the co-option function of the Board (co-opted members must be less than elected members). Through processes of whānau group mandate, the Māori community determines its representatives to the governance partner Te Whao Urutaki. Te Whao Urutaki then decides which of its members will take up these co-opted Board positions. Though the legal need to co-opt Te Whao Urutaki onto a single Board structure is not ideal, the process adopted protects an Indigenous mandating process (within the Indigenous community) and ensures Te Whao Urutaki accesses the full powers of the Board of Trustees.

Here, the parameters of the legislated governance structure of schools in New Zealand has been stretched to its limits to operate a co-governance arrangement that upholds an unsanctioned (by the state) and politically contentious interpretation of the Treaty. The co-governance structure has meant facing deeply political and ethical questions, and taking courageous and risky decisions. It does not follow the traditional and safer route of inclusion, but rather, in acknowledging two forms of governing authority, has taken a more uncertain path, involving the possibility of ongoing contestation, and of committed engagement, and therefore of relational justice.

\section{Māori Political Practice}

Forms of Māori language education had been operating at Newton Central since 1993. In 1997, a total immersion unit Te Uru Karaka (Māori is the language of instruction 100\%) was established catering to families who sought fluency in the Māori language for their children. It was this unit that my family joined in its foundation year. By 2000, Te Uru Karaka was attracting large numbers of students and had developed a strong philosophy and practice. Regular meetings were held. Decision-making, meeting, and enrolment criteria and protocols were in place. Whānau were actively engaged in curriculum development, classroom and resource support, and the development of a range of initiatives, including language learning for families, the development of organic gardens, and various Māori ceremonies and celebrations such as Matariki iv . Members of Te Uru Karaka were/are politicized, educated and highly committed to ensuring their children, unlike ourselves, are raised with Māori as a first language. We also understood that working along collective whānau lines, and with shared cultural and political values, meant we were strong.

When the conflict arose between ourselves and the school, we were both angry and shaken, but rallied quickly to show collective leadership both for the Māori pathways and for the school. Had our stance been primarily oppositional, focusing on our victimization and the schools oppressive wrong doing- a very different outcome was likely. That approach would have led to opposition, disengagement and distrust, shifting our focus from creative cultural and educational action in Te Uru Karaka, to a series of power struggles with school management. Instead we recognized the need to address the fundamental issue of power and decision-making as the basis for the possibility of good relations. The Treaty provided the model of power sharing and with that were able to move from opposition to a radical, yet constructive proposal for co-governance.

The whānau came to the Board of Trustees with a way forward. We came willing to teach and to lead, and showed ourselves to be committed and relational. To their credit the Board maintained an open and responsive orientation in the face of significant pressure and dissent. The Board not only did not close down the concerns and aspirations of the Mâori community, they mandated the Māori community to write the Treaty governance policy. Their ratification of a 'radical'v policy suggests a courageous political decision that facilitated the rapid movement from 
opposition to relationship, furnishing the conditions for the development and growth of a quality Māori education option.

Though this movement required particular capacities on both sides, my interest here is the Māori response and what might be learnt from that for productive political Indigenous practice. Important as our critical political capabilities were to framing these new governance arrangements, it was our cultural ways of being and doing that enabled the shift. These ways of being center affective and relational face to face engagement. They are practices of aroha (love and compassion), manaaki (care for the being and dignity of others) and whanaungatanga (unity and collectivity). They encourage affective expression (tears, laughter and anger) held safely by longstanding cultural practices like karakia (prayer and incantation), mihimihi (acknowledgement and greeting), kōrero (talk) and waiata (song). These ways of being are ordinary for the Māori community at Newton Central School (as they are elsewhere). They are present in our more formal activities of meeting with ourselves and with others (including the Board of Trustees meeting where Māori rituals of karakia begin and end meetings), they are present in daily meaningful ways in the life of the classroom (embedded in the pedagogy management and culture), they are present in the many rituals and celebrations initiated and enacted by the whānau and school community.

These ways of being were crucial in holding space and making safe our engagements with the school during the conflict. It was because we could draw on a primary cultural ethic of relationality (rather than opposition) in our engagement with the Board that assisted them to embrace the proposals for co-governance and power sharing. Consequently, the co-governance relationship has worked to Indigenize the culture of the entire school. School events, celebrations and day to day activities, student-teacher relationships, management practices and planning and curriculum content, in meaningful ways reflect knowledge of, engagement with and respect for the Māori world. And this engagement is not simply with Māori cultural practices, but (through a specialized curriculum taught at every year level) is also engagement with deeply critical and political questions about our 'nation', its history and contemporary debates.

It seems to me, we (Māori) often overlook the power of these 'cultural' practices and ways of being for catalyzing change. We might see them as just the way we do things, or we might even think that our cultural practices of aroha (compassion) for example, make us weak in the face of coloniality. We rarely consider these practices for their political valence, for the ways our daily practices can interrupt regularities of power and through which commitments to social justice can be ignited - as they have at Newton Central School.

Indigenous political theory and practice can do this work. Disengagement and oppositional political stances alongside struggles for recognition and inclusion are necessary in the face of ongoing forms of colonization. But they also maintain our identification with colonizing logics and can separate us from our powers - those unique, always relational ways of being and doing in the world - from which Indigenous ethical and political practices can flourish. 


\section{Endnotes:}

i Whānau is a term used extensively to denote the collective structure of 'family'. The use of the term contemporarily might include reference to a nuclear-sized family, the extended kin family (more traditional use), and to a range of groups brought together around a shared focus or activity. Whānau has been a particularly useful concept and structure in the context of urbanisation and cultural and political practice.

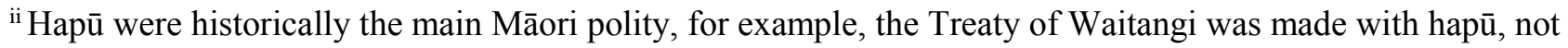
the larger 'iwi' groupings which have come to dominate contemporarily, particularly in the context of CrownMāori relations and Treaty of Waitangi settlements.

iii The term 'kawanatanga' is a transliteration of governorship. In discussions between Māori-hapu and the missionaries (who were involved in translating oral communication and the Treaty text itself) at Waitangi leading up to the signing of the Treaty, it was stressed by Hobson and others that British Crown needed the powers of 'kawanatanga' in order to manage the behaviour of their own subjects in Aotearoa. The lawlessness of British subjects was an ongoing complaint among Māori. See Orange, C. (2004). An illustrated history of the Treaty of Waitangi. Wellington, New Zealand: Bridget Williams Books. See also Walker, R. (2004). Ka whawhai tonu mātou: Struggle without end. Auckland, New Zealand: Penguin.

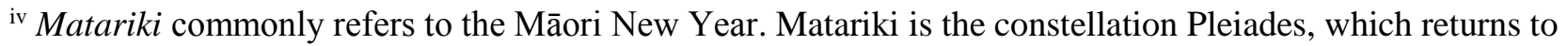
New Zealand skies in late June and heralds the beginning of the New Year. The return of Matariki was traditionally greeted with various rituals associated with the promise of a bountiful year ahead.

$v$ 'Radical' in the sense that no other school in Aotearoa New Zealand operates a governance structure that works as a partnership that fully shares power. In most other Boards, there is likely to be one or two Māori Board members (if any), who are often isolated and easily outvoted on matters pertaining to Māori. See Graham, J. (2003). Kanohi ki te kanohi: Establishing partnership relationships between schools and Māori communities. SET Research Information for Teachers (2).

\section{References}

Barlow, C. (1991). Tikanga whakaaro: Key concepts in Māori culture. Auckland, New Zealand: Oxford University Press.

Hoskins, T. K. (2017). Te ara whanaunga: Relations on the ground at Waitangi Tribunal hearings. In R. Bell, M. Kawharu, K. Taylor, M. Belgrave, \& P. Meihana (Eds.), The Treaty on the ground: Where we are headed, and why it matters (pp. 133-150). Auckland, New Zealand: Massey University Press, Auckland.

Hoskins, T. K. C. (2010). Māori and Levinas: Kanohi ki te kanohi for an ethical politics (Unpublished Doctoral Thesis). The University of Auckland, New Zealand.

Hoskins, T. K. C. (2012). 'A Fine Risk: Ethics in Kaupapa Maori Politics'. New Zealand Journal of Educational Studies, 47(2), 85-99.

Marsden, M. (2003). The woven universe: Selected writings of Rev. Māori Marsden. Otaki, New Zealand: Estate of Rev. Māori Marsden.

Cultural and Pedagogical Inquiry, Fall 2018, 10(2), pp. 161-165

ISSN 1916-3460 @ 2018 University of Alberta

http://ejournals.library.ualberta.ca/index.php/cpi/index 